endarterectomy had not become symptomatic. The statistical analysis by intention to treat seems to balance this noncompliance. Median follow up is short ( $2 \cdot 7$ years), and the five year rates of stroke and death combined, for both the surgical $(4.8 \%)$ and the medical groups $(10.6 \%)$, are Kaplan-Meier projections. The efficacy of endarterectomy in women is one third less than that in men owing to more perioperative complications in women. There does not seem to be an increased risk of stroke with increasing degree of stenosis, which is a feature of symptomatic trials, but the numbers in the subgroups are relatively small. Overall there is no difference between surgical and medical groups in the outcome of any major stroke or death (116 medical patients, 100 surgical patients).

\section{Need for selection and caution}

Despite these methodological flaws the study has clear messages for any clinician intending to offer surgery to patients with asymptomatic disease: since duplex ultrasound scanning had a positive predictive value of $95 \%$ and $x$ ray contrast angiography carried a risk of stroke of $1.2 \%$, selection should be by safe non-invasive duplex investigation augmented by magnetic resonance angiography when necessary. It is also apparent that surgical intervention should be performed only in highly selected patients without severe cardiac risk and in a surgical environment with a track record of low operative mortality.

At present the question of what to do for patients with asymptomatic carotid artery disease remains open. Data on the natural course of the disease are contradictory, and, until recently, studies of operative intervention have been inconclusive. Early results from the ACAS study may well have made the clinician's decision more difficult. In 1993 Barnett and Haines advised clinicians not to rush the pace of change, reminding therapeutic enthusiasts of an old gardener's axiom, "Flowers do not grow more quickly if we pull on them."14 The ACAS study could also alienate referring groups traditionally wary of surgical intervention in carotid disease. In a recent editorial Warlow used a population based argument and discounted individual benefit, suggesting that surgery on patients with asymptomatic disease is inappropriate. ${ }^{15}$

Progress will depend on calm appraisal of the available data. The North American Symptomatic Carotid Endarterec- tomy Trial suggested that four carotid endarterectomies in symptomatic patients would prevent one stroke a year. ${ }^{2}$ The data from the ACAS study suggest that among asymptomatic people nearly 20 carotid endarterectomies would be needed to prevent one stroke in every five years. ${ }^{13}$ If clinicians are in doubt about whether to offer surgery to patients with asymptomatic disease, the management of choice is to investigate with duplex ultrasound scanning, select patients carefully, and enrol them in the European ACST trial.

Craig D Irvine is supported by the Stroke Association.

CRAIG D IRVINE

Research fellow in surgery

ROGER N BAIRD

Consultant surgeon

PETER M LAMONT

Consultant surgeon

Department of Surgery,

Royal Infirmary,

Bristol BS2 8HW

ALUN H DAVIES

Senior lecturer

Department of Surgery,

Charing Cross Hospital,

London W6 8RF

1 Eastcott HHG. Carotid endarterectomy: a mid-Atlantic view. $\mathrm{Br} f$ Surg 1986;73:865.

2 North American Symptomatic Carotid Endarterectomy Trial Collaborators. Beneficial effect of carotid endarterectomy in symptomatic patients with high grade stenosis. $N$ Engl $f \mathrm{Med}$ 1991;325:445.

3 European Carotid Surgery Trialists' Collaborative Group. MRC European carotid surgery trial: interim results for symptomatic patients with severe $(70-99 \%)$ or with mild $(0-29 \%)$ stenosis.

4 Baird RN, Lambert M. Controversies in management. Should carotid endarterectomy be purchased? $B M \mp$ 1995;310:315.

5 Timsit SG, Sacco RL, Mohr JP, Foulkes MA, Tatemichi TK, Wolf PA, et al. Early clinical differentiation of cerebral infarction from severe atherosclerosis and cardioembolism. Stroke 1992;23:486.

6 Chambers BR, Norris JW. The case against surgery for asymptomatic carotid stenosis. Stroke 1984;15:605.

Autret A, Pourcelot L, Saudeau D, Marchal C, Bertrand P, de Boisuilliers S. Stroke risk in patients with carotid stenosis. Lancet 1987 ; i:888.

8 Moore WS, Barnett HLM, Taylor DW, Beebe HG, Bernstein EF, Brener BJ, et al. Guidelines for carotid endarterectomy. Stroke 1995;26:188.

9 Thompson JE, Patman RD, Talkington CM. Asymptomatic carotid bruit: long-term outcome of patients having carotid endarterectomy compared with controls. Ann Surg 1978;188:308

10 CASANOVA Study Group. Carotid surgery versus medical therapy in asymptomatic carotid stenosis. Stroke 1991;22:1229.

11 Mayo Asymptomatic Carotid Endarterectomy Study Group. Effectiveness of carotid endarterectomy for asymptomatic carotid stenosis: design of a clinical trial. Mayo Clin Proc 1989;64:897.

12 Hobson RW (II), Weiss DG, Fields WS, Goldstone J, Moore WS, Towne JB, et al. Efficacy of carotid endarterectomy for asymptomatic carotid stenosis. $N$ Engl f Med 1993;328:221.

13 Executive Committee for the Asymptomatic Carotid Atherosclerosis Study. Endarterectomy for asymptomatic carotid artery stenosis. $\mathcal{F} A M A$ 1995;273:1421.

14 Bamett HJ, Haines SJ. Carotid endarterectomy for asymptomatic carotid stenosis [editorial comment]. N Engl f Med 1993;328:276.

15 Warlow C. Endarterectomy for asymptomatic carotid stenosis. Lancet 1995;345:1254.

\title{
Hunger strikes
}

\section{Can the Dutch teach us anything?}

A hunger strike "is an age-old ritual act which can serve so many motivations and exigencies that it can be as corrupt as it can be sublime" noted Erikson in his study of Gandhi's nonviolent tactics. ${ }^{1}$ Within the past few years there have been well publicised hunger strikes for various causes in many countries, including the United States, the former Soviet Union, China, South Africa, Sudan, Poland, the former Yugoslavia, Bangladesh, France, Egypt, Canada, Israel, and the Netherlands.

Although deaths are rare, the power of the hunger strike comes from the striker's sworn intent to die a slow death in public view unless those in power address the injustice or condition being protested about. Hunger strikers are not suicidal and would greatly prefer responses to their demands.
The most intractable hunger strikes, from a human rights and medical ethics perspective, are those carried out by people in the custody of the state, usually in prisons or other detention centres. In this context deaths have occurred-most notably those of 10 Irish hunger strikers in Maze prison in Northern Ireland in 1981.

Hunger strikers present two primary ethical issues for doctors-when is it ethical to force feed a competent adult hunger striker and when is it ethical to artificially provide nutrition to a hunger striker who has become incompetent or unconscious? Medical groups have provided conflicting ethical advice on the first issue and virtually no guidance on the second. American courts have ruled that a prisoner who is on a hunger strike to obtain a transfer or for better living 
conditions may legally be force fed if necessary. ${ }^{2}$ Of course, legal authority to treat is not the same as ethical justification to override authority.

In Britain the most definitive ethical statement remains the 1974 statement of the BMA's central ethics committee that prison doctors "must" have the "final decision" on intervening in prison hunger strikes. ${ }^{2}$ The BMA's position rejects, wrongly in my opinion, the proposition that force feeding a competent adult, who should always have the ethical authority to refuse medical treatment, is always "torture." The World Medical Association states that the doctor should act with the hunger striker as in any other doctor-patient relationship. The association, however, avoids taking a position on the most difficult issue of what the doctor should do after the hunger striker loses competence or consciousness, leaving individual doctors to do what they consider to be "in the best interests of the patient." 3

The lack of definitive ethical standards caused consternation in the Netherlands in 1991 when a group of 180 Vietnamese refugees began a long hunger strike. The strike prompted the Johannes Wier Foundation for Health and Human Rights to organise a seminar on assistance for hunger strikers in 1992 in cooperation with the Royal Dutch Medical Association. This seminar was the basis for a pamphlet that has just been made available in English. ${ }^{4}$ The pamphlet itself relies heavily on the BMA's report, Medicine Betrayed, published in 1992.5

The pamphlet makes two concrete suggestions, both of which unfortunately raise more questions than they answer. The first is that hunger strikers should be asked to fill out documents, modelled on the living will, called a "statement of non-intervention," in which they set forth their instructions regarding medical intervention after they lose competence. But does the model of the living will apply? Is the degradation of forced feeding eliminated when the patient becomes unconscious? Is the doctor's role in accepting the written statement at face value more political than medical?

We will not find the "solution" to the political tactic of a hunger strike either by trying to medicalise the hunger strike or by inventing new forms for hunger strikers to sign. Indeed, the Dutch written instruction simply serves to highlight the doctor's ethical dilemma in choosing between the unconscious hunger striker's life or liberty. This is because reasonable hunger strikers could sign a "statement of non-intervention" and then privately instruct their doctor to ignore the statement if treatment became necessary to save their life. The signed form would thus serve a political purpose of making hunger strikers seem more resolute while counting on their doctors to save their lives should the hunger strike fail to meet the strikers' objectives.

The document also suggests that for prisoners an independent "doctor of confidence" be made available to the hunger striker. Of course prisoners should have access to doctors who can practice medicine free of state control, just as they must have access to their own lawyers; but what rules should this "doctor of confidence" follow? What position should a prison doctor take in countries where no such alternative doctors are available, and how should prison doctors who refuse to participate in torture or force feeding be protected themselves?

Perhaps the most arresting aspect of the Dutch document, representing as it does the thinking of members of the only society to approve of euthanasia by doctors, is what it leaves out. While the document was being prepared, in early 1993, a 65 year old Dutch patient with cancer went on a highly publicised hunger strike after her doctor refused to end her life though mercy killing. After 12 days her request for euthanasia was agreed to by another doctor. ${ }^{7}$ This case raises several issues. What role should this woman's doctor have had? Could the second doctor be considered to be a doctor of confidence? What is the relation between the right to refuse treatment (including force feeding) and the right to demand treatment (including euthanasia)?

There is no credible international body capable of articulating standards for medical ethics let alone a plan to enforce them. ${ }^{8}$ Until one is created, individual doctors will be forced to muddle through as best they can, using the general principles of consent and confidentiality in settings where they often have little practical meaning for either the doctors or their patients.

\section{GEORGE J ANNAS} Professor

Health Law Department,

Boston University Schools of Medicine and Public Health,

Boston,

MA 02118 ,

USA

1 Erikson EH. Gandhi's truth: on the origins of militant nonviolence. New York: Norton WW, 1969:417. 2 Ethical statement: artificial feeding of prisoners. BMF 1974;iii:52-3.

3 World Medical Association. Declaration of Malta on hunger strikers (adopted by the 43rd world medical assembly in Malta in 1991 and revised at the 44th assembly in Marbella in 1992). Geneva: WMA 1992

4 Assistance in hunger strikes: a manual for physicians and other health personnel dealing with hunger strikers. Amersfoort: Johannes Wier Foundation for Health and Human Rights, 1995.

5 British Medical Association. Medicine betrayed: the participation of doctors in human rights abuses. London: Zed Books, 1992.

6 Benatar SR. Detention without trial, hunger strikes and medical ethics. Law, Medicine and Health Care 1990;18:140-5.

7 Hunger striker succeeds: euthanasia for Dutch woman. Chicago Tribune 1993 Mar 23:4.

8 Grodin MA, Annas GJ, Glantz LH. Medicine and human rights: a proposal for international action. Hastings Cent Rep 1993;23(4):8-12.

\section{Management of blood loss in Jehovah's Witnesses}

\section{Recombinant human erythropoietin helps but is expensive}

The Jehovah's Witness religion was founded in the late 1870 s by Charles Russell in Pittsburgh, Pennsylvania. There are 5 million Jehovah's Witnesses worldwide and 125000 in the United Kingdom. Members of this sect do not accept blood transfusions, a stand based on passages from the Bible, such as this from Leviticus: (xvii) "As for any man who eats any sort of blood, I shall certainly set my face against the soul that is eating the blood, and I shall indeed cut him off from among his people." Blood transfusion is interpreted as the eating of blood, and Jehovah's Witnesses believe that all hope of eternal life will be forfeited if transfusion is accepted. Autologous transfusion is also prohibited because they believe that once blood has left the body, it is then unclean. These prohibitions present ethical and clinical challenges to doctors who look after seriously ill or injured Jehovah's Witnesses and prompt a search for alternatives to blood.

The courts have consistently upheld Jehovah's Witnesses' decisions to refuse transfusions on the grounds that any adult of sound mind has the right to determine what shall be done with his or her own body. Nevertheless, two thirds of European doctors working in intensive care units would give transfusions to an unconscious Jehovah's Witness who was losing blood, and $41 \%$ would not inform the patient later. ${ }^{1}$ Doctors from France, Spain, and Italy are more inclined to 